duced after calcination in air the ketone was formed predominantly along with a small amount of 2-propanol. X-Ray analysis showed the existence of nickel oxide in I in addition to metallic nickel and stoichiometric titanium carbide, whereas in $\mathrm{II}$ a small amount of titanium dioxide in rutile form existed in addition to the above species. Both nickel oxide on the carbide (III) and nickel on rutile $(N)$ exhibited some activity for the acetone hydrogenation; the main product was the alcohol over III and the ketone over $\mathrm{N}$. Over unsupported nickel the ketone was not formed.

It is concluded from the experimental results that the catalyst systems which consisted of nickel with or without its oxide and titanium carbide with or without titanium dioxide caused the simultaneous formation of the alcohol and the ketone in the hydrogenation of acetone.

\title{
金属パラジゥム触媒による酶酸中での オレフィンのアセトキシル化反応122
}

(1972 年 12 月 11 日 受 理)

山添 書*. 後藤頼 信**. 田中隆夫*. 清山哲 郎*

オレフィン部分酸化に打ける金属パラジウムの特異な触媒作用を解明するために, 酢酸中に㧍けるオ レフィンの接触的アセトキシル化反応をプロピレンおよび $n$-ブテンを用いて調べた。プロピレンのア セトキシル化反応では, 活性炭担持パラジウム触媒を用いた場合酶酸イソプロペニルも生成するが，金 属パラジウムの触媒作用によるものは酢酸アリル $\left(\mathrm{P}_{1}\right)$ だけである。一方, $n$-ブテンのアセトキシル化 反応はやや複雑である。この場合，金属パラジウムの触媒作用に帰せられる生成物として $\mathrm{CH}_{2}=\mathrm{CH}$. $\mathrm{CH}(\mathrm{OAc}) \mathrm{CH}_{3}\left(\mathrm{~B}_{1}\right), \mathrm{CH}_{3} \mathrm{CH}=\mathrm{CHCH}_{2} \mathrm{OAc}\left(\mathrm{B}_{4}\right), \mathrm{CH}_{2}=\mathrm{CHCH}=\mathrm{CHOAc}$ のシスおよびトランス異性体 $\left(\mathrm{B}_{6}, \mathrm{~B}_{6}\right)$ 拉よび 1 個の未同定物質 $\left(\mathrm{B}_{3}\right)$ が得られ，その生成物分布は $n$-ブテンの種類や触媒の状態に よっていちじるしく変化する。これらの結果において $n$-ブテンから $\mathrm{B}_{1}, \mathrm{~B}_{4}$ が生成する事実はプロピ レンから $\mathrm{P}_{1}$ が生成することとともに主反応に対して $\pi$-アリル機構が適用できることを示するのであ ろう。ただし， $n$-ブテンのアセトキシル化反応での複雑な結果を説明するには副反応るまた考慮しなけ ればならない。これらについて承相懸濁パラジウム触媒によるオレフィン部分酸化と関連させつつ考察 した。

\section{1 緒 言}

著者らは，さきに水相中に懸濁したパラジウム黒を触媒として オレフィンと酸素を反応させると, 高収率で不飽和のアルデヒ ド，カルボン酸あるいはケトンが生成することを見いだし報告し た2)テ5)。この反応では, オレフィンのアリル水素引き拔きたよる

1）この報文を“金属パラジウムによるオレフィンの液相酸化 反応の研究 (第 2 報)”とする.

2）前報(第 1 報), 清山哲郎, 荒牧稔, 竹山尚蜸, 山添㕷, 工化, 74, 672(1971).

* 九州大学工学部応用化学教室, 福岡市東区箱崎

** 現在 化成水島株式会社, 岡山県倉敷市

3）山添星, 荒牧稔, 北条純一, 清山哲郎, 触媒研究発表 会予稿集, p. 67 (1970).

4) T. Seiyama, N. Yamazoe, J. Hojo, M. Hayakawa, J. Catal., 24, 173(1972). $\pi$ ーアリル中間体の生成と，それに対する $\mathrm{OH}^{-}$(あるいは水) 付 加が重要な反応過程となっており，拈とらくこれが金属パラジウ ムを用いての通常の気相酸化反応にくらべ部分酸化の選択性が高 い理由であろら。要するに金属パラジゥムによるオレフィンの液 相酸化では, オレフィンのパラジウム上への吸着, 脱水素と夜相 成分の付加といら反応形式に特改があるように考えられる。この 点, 水以外の夜相成分についても興味がもたれるが, ここでは酢 酸中での酸化反応（アセトキシル化反応）について報告する。

パラジゥム塩触媒一眽酸系に批けるオレフィンの酸化について は,すでに Moiseev ら゙ををはじめとして幾多の研究が行なわれて 扣り，総説7) も書かれている。一方，金属パラジウム触媒を用い

5）山添 㕷, 早川方雭, 江頭誠, 清山哲郎, 触媒, 14, 35 (1972).

6) I. I. Moiseev, M. N. Vargaftic, Dokl. Akad. Nauk USSR, 133, $377(1960)$. 


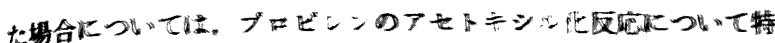

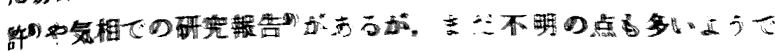
ある。

\section{2 実 法}

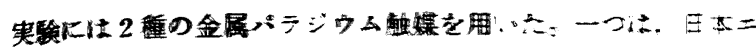

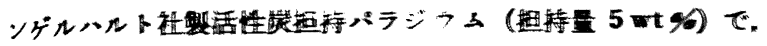

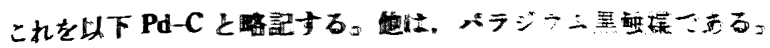

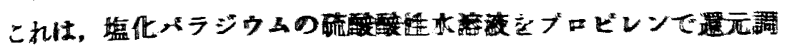

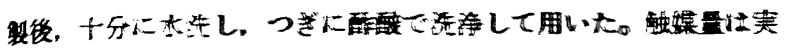

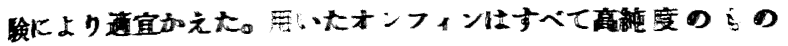

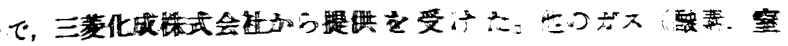

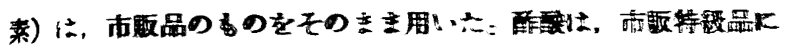

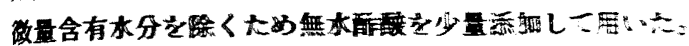

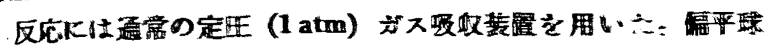

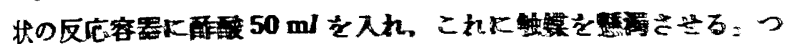

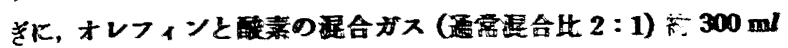

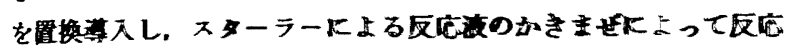

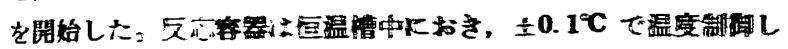

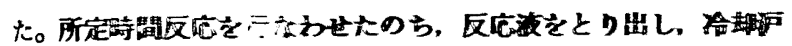
過してただらにガスフママトグラフで分析した。カラム元テン䒺 にはナペこPEG 1000 を用いた。

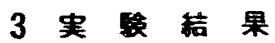

\section{1 フロビレンのアセトキシル化反店}

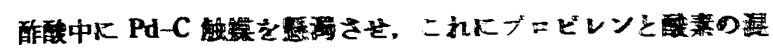

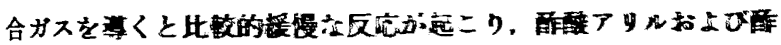

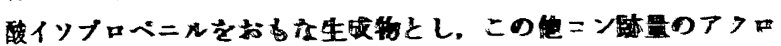

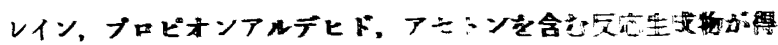

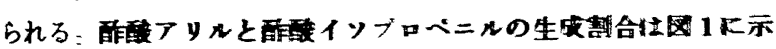

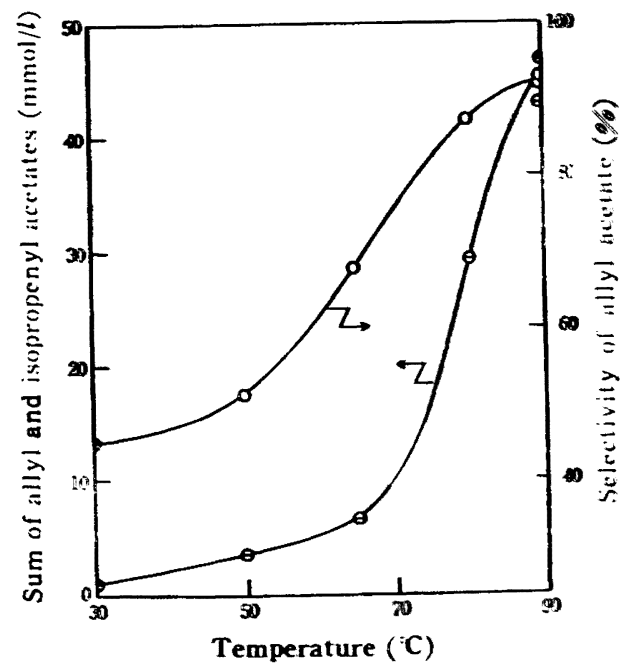

Fig. 1 Temperature dependence of the propylene acetoxylation reaction

$$
P_{\mathrm{C}: \mathrm{H}_{4}} P_{\mathrm{O}:}=2,1 \mathrm{hr}, \mathrm{Pd}-\mathrm{C} 0.6 \mathrm{~g}
$$

7）たとえに. E.S.Stern, Catal. Rev., 1. 74(1968).

8) Farbenfabriken Bayer, Fr. P., 1, 346, 219(1963),

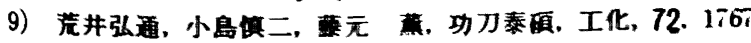
(1969).

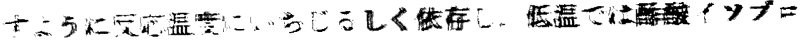

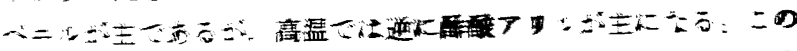

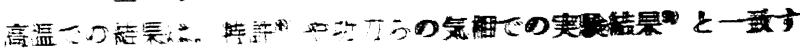

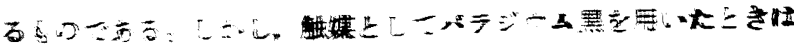

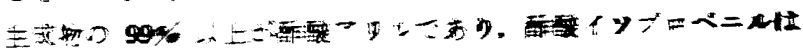

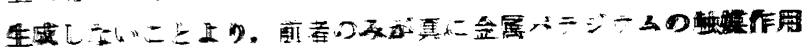

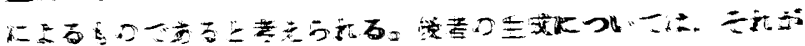

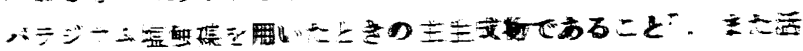

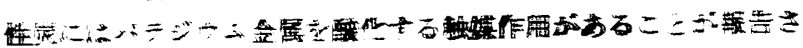

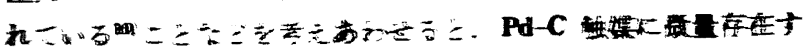

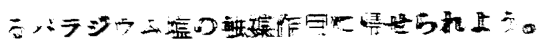

32 ロブテンのアセトキシに・原

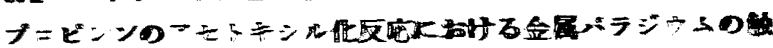

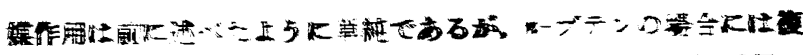
群である。四このニ5K

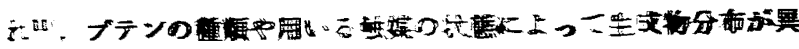
二る:

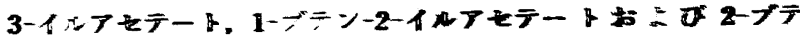

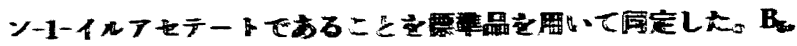

$\mathrm{CH}_{2}=\mathrm{CH}-\mathrm{CH}-\mathrm{CH}_{3} \quad \mathrm{CH}_{3}=\mathrm{C}-\mathrm{CH}_{2}-\mathrm{CH}_{3} \quad \mathrm{CH}_{2}-\mathrm{CH}=\mathrm{CH}-\mathrm{CH}_{3}$ $\begin{array}{cccc}\text { OAc } & \text { OAc } & \text { OAc } & \\ \left(B_{1}\right) & B_{2} & & \text { (B) }\end{array}$

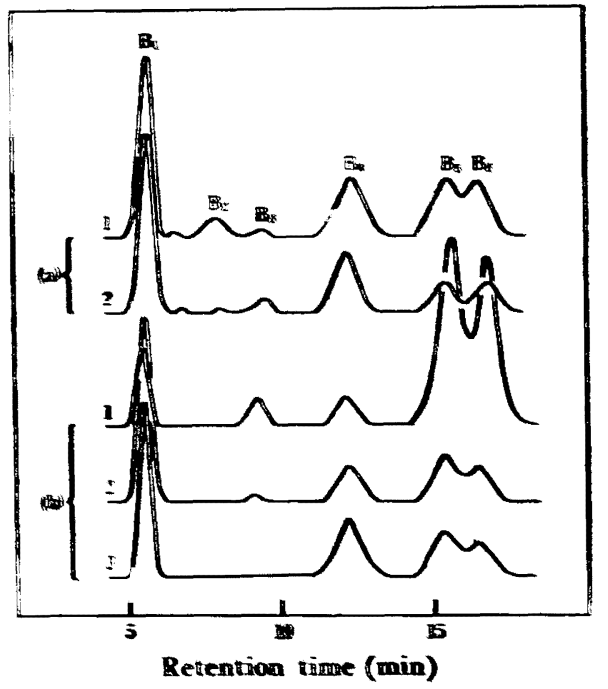

Fig. ? Gas chromatograms of the acetoxylation products of -butemes catalysed by Pd-C (a) or palladiuan black (b)

Numbers 1, 2 and 3 show the reaction products of 1butene, cis-2-butene, and trems-2-batene, respectively. $\mathrm{B}_{1}: \mathrm{CH}_{3}=\mathrm{CHCH}(\mathrm{OAc}) \mathrm{CH}_{3} \mathrm{~B}_{3}: \mathrm{CH}_{2}=\mathrm{C}(\mathrm{OAc}) \mathrm{CH}_{2} \mathrm{CH}_{3}, \mathrm{~B}_{3}$ : Unidentified, $\mathrm{B}_{4}: \mathrm{CH}_{5} \mathrm{CH}=\mathrm{CHCH}_{4} \mathrm{OAc}, \mathrm{B}_{5}, \mathrm{~B}_{6}: \mathrm{CH}_{8}=\mathrm{CHCH}=$ CHOAC (Cis and trans)

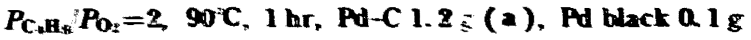
(b)

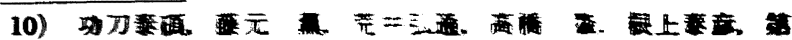

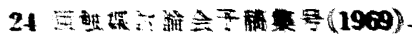

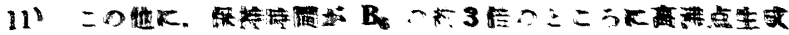

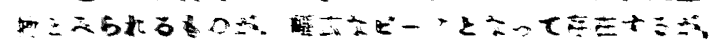

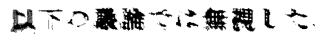


Table 1 Acetoxylation of $n$-butenes over three kinds of catalysts ${ }^{a}$ )

\begin{tabular}{|c|c|c|c|c|c|c|c|c|}
\hline \multirow{2}{*}{ Catalyst } & \multirow{2}{*}{ Olefin } & \multirow{2}{*}{$\begin{array}{l}\text { Gas con- } \\
\text { sumption } \\
\text { (mmol) }\end{array}$} & \multicolumn{6}{|c|}{ Product distribution $(\%)$} \\
\hline & & & $B_{1}$ & $\mathrm{~B}_{2}$ & $\mathrm{~B}_{3}$ & $B_{4}$ & $\mathrm{~B}_{6}$ & $\mathrm{~B}_{6}$ \\
\hline \multirow{2}{*}{$\begin{array}{l}\mathrm{Pd}-\mathrm{C}(1.2 \mathrm{~g}) \\
\text { No treatment }\end{array}$} & 1-Butene & 1.96 & 29 & 10 & 8 & 20 & 17 & 16 \\
\hline & cis-2-Butene & 1.27 & 55 & 1 & 6 & 22 & 8 & 8 \\
\hline \multirow{4}{*}{$\begin{array}{l}\text { Pd-C (1.2 g) } \\
\text { Dried at } 100^{\circ} \mathrm{C} \\
\text { for } 1 \mathrm{hr} \text { in vacuo }\end{array}$} & 1-Butene & 2.8 & 14 & 4 & 8 & 15 & 34 & 25 \\
\hline & cis-2-Butene & 1.29 & 52 & 0 & 4 & 16 & 15 & 13 \\
\hline & trans-2-Butene & 0.98 & 51 & 2 & 3 & 23 & 10 & 11 \\
\hline & 1-Butene & 2.20 & 7 & 0 & 4 & 5 & 48 & 36 \\
\hline \multirow[t]{2}{*}{ Pd black $(0.1 \mathrm{~g})$} & cis-2-Butene & 1.36 & 54 & 0 & 0 & 8 & 22 & 16 \\
\hline & trans-2-Butene & 1.17 & 45 & 0 & 0 & 14 & 25 & 16 \\
\hline
\end{tabular}

a) Reaction condition $P_{\mathrm{C}_{4} \mathrm{H}_{8}} / P_{\mathrm{O}_{2}}=2,90^{\circ} \mathrm{C}, 1 \mathrm{hr}$.

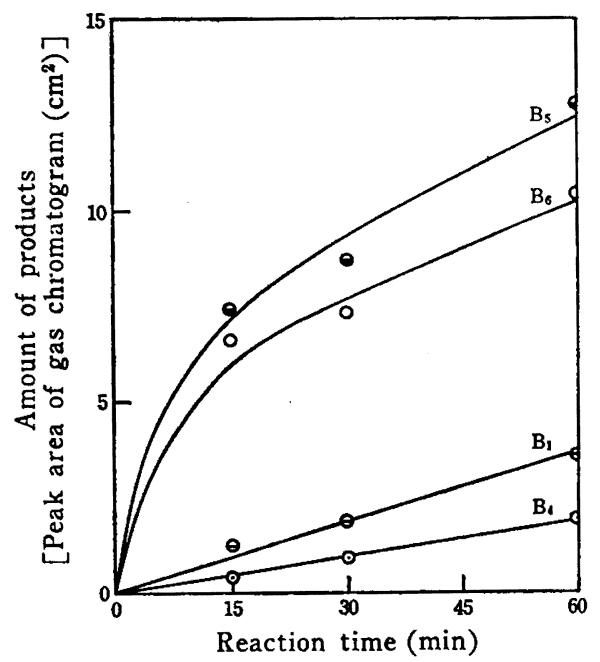

Fig. 3 Acetoxylation of 1-butene over palladium black catalyst

$P_{\mathrm{C}_{4} \mathrm{H}_{8}} / P_{\mathrm{O}_{2}}=2,90^{\circ} \mathrm{C}$, Palladium black $0.1 \mathrm{~g}$

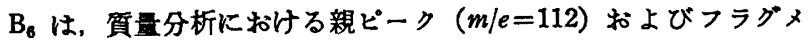
ソト $(m / e=69,43), \mathrm{NMR}$ におけるメチルプロトンとどニルブ ロトンのプロトン比 (3: 5) から,つぎの三つのブタジェン型エ ステルが推定されたが, さらにビニルプロトンの化学シフトか<smiles>CC(C)=O</smiles>

$\left(B_{8}\right)$<smiles>C=CC(=C)OC(C)=O</smiles><smiles>C=CC=COC</smiles>

$\left(\mathrm{B}_{6}\right)$
ら，Matter らの推定法 ${ }^{12)}$ 用いて，上記のように $\mathrm{B}_{6}$ では酢酸 基が炭素骨格に対しシス位に， $\mathrm{B}_{6}$ ではトランス位に付加した構 造であると決定した。B いない。

ところでこれらの生成物のらち， $\mathrm{B}_{6}$ と $\mathrm{B}_{8}$ は図2 亿見られるよ 5に 2-プテンよりる 1-ブテンから生成しやすく，また $\mathrm{Pd}-\mathrm{C}$ 触 媒よりるパラジウム黒触媒を用いたとさに生成しやすい。また， 触媒状熊と生成物分布の関係を示した表 1 からわかるように，同 じ Pd-C 触媒でも，これを $100^{\circ} \mathrm{C} て ゙ 1$ 時間乾燥処理をした場合，

12) U. E. Matter, C. Pascual, E. Pretsh, A. Pross, W. Simon, S. Sternhall, Tetrahedron, 25, 691(1969).
活性の向上とともに $\mathrm{B}_{6} ， \mathrm{~B}_{6}$ の生成割合が増加する。なお表 1 の 生成物分布は，水素炎ガスクロマトグラフのピーク面積から全生 成物についてモル感度を同一として求めた。

$\mathrm{B}_{5} ， \mathrm{~B}_{6}$ の生成と触媒活性の相関は，反応の時間变化を追跡す ることによっても確かめられた。図3はパラジウム黒触媒を用い ての 1-ブテンのアセトキシル化反応について， $B_{1} ， B_{4}, B_{5}$ 扰よ び $\mathrm{B}_{6}$ の生成量の時間变化を調べたものである。この実験に括い ては, 反応容器に㑡枝をつけ，そこからマイクロシリンジを挿入 して，反応を中断することなく随時少量の反応液を採取し，ガス クロマトグラフ分析した。図のように， $\mathrm{B}_{1}$ と $\mathrm{B}_{4}$ は反応の全区間 でほとんど一定速度で生成するが， $\mathrm{B}_{6}$ と $\mathrm{B}_{6}$ は触媒活性の大きな 反応初期に急速に生成し，時間ととすに速度低下をきたすことが わかる。

\section{4 考而}

パラジウム系触媒によるオレフィンのアセトキシル化反応のう ち，パラジウム塩の触媒作用については相当によく研究され，パ ラジウムイオンとオレフィンとの $\pi$ 錯体を経由する反応機满が定 説7) となっている。一方, 金属パラジゥム触媒については, プロ ピレンから高収率で酢酸アリルが生成することが特許到として知 られていたが，その後荒井ら9)は気相接触反応でそれを確かめ， その機構として $\pi$ ーアリル中間体に酢酸基が付加するといらつぎ のよらな $\pi$ アリル中間体機構を提出した。たたし，酢酸アリル

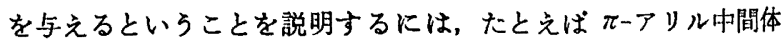
のかわりにのーアリル中間体を考えてむよく，これを証明するに は,ささらに $n$-ブテンの反応る検討する必要があろう。

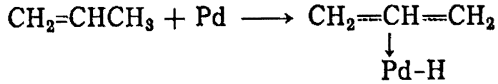

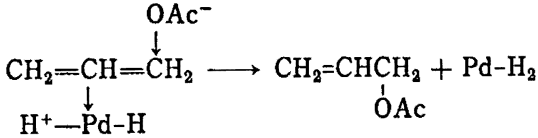

$$
\begin{aligned}
& \mathrm{Pd}-\mathrm{H}_{2}+1 / 2 \mathrm{O}_{2} \longrightarrow \mathrm{Pd}+\mathrm{H}_{2} \mathrm{O}
\end{aligned}
$$

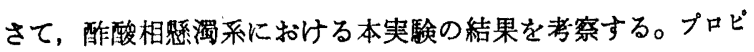
レンの反応では, 酢酸アリル扰よび酢酸イソプロペニルのニつが 生成物として得られ，そのらち，金属パラジウムの触媒作用によ るものは前者だけである。この結果は，もちろん, $\pi$ るアリル中間 体機構と矛盾しないが，それ以上の知見を引きたすことはできな い。一方，nーブテンの反応では，金属パラジウムの触媒作用によ るものとして五つの生成物が得られ（1-ブテン-2-イルアセテー 
ト $\left(\mathrm{B}_{2}\right)$ は, プロピレンの反応における酢酸イソプロペニルの生 成と同しく，微置のパラジウム塩の触媒作用によるものと考えら れる)，結果は複雑であるが，知見はより照富である。まず 1-プ テン，2-ブテンいずれる，1-ブテン-3-イルアセテート $\left(\mathrm{B}_{1}\right)$ およ

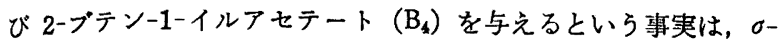
アリル中間体への酢酸基の付加といらことでは説明が困難で， $\pi$ アリル中間体機構を支持するるのと解釈される。すなわち、nーブ テンから導かれる $\pi$-アリル中間体は, syn 型, anti 型の区別 ${ }^{18)}$ を別にすればブテンの種類にかかわらずすへて同一で，したがっ て酰酸基の付加によって，とすに $\mathrm{B}_{1}$ および $\mathrm{B}_{4}$ を与えるからで ある。

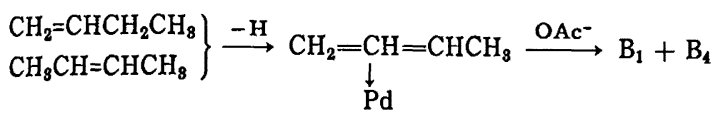

つぎに他の三つの生成物 $\left(\mathrm{B}_{3}, \mathrm{~B}_{6}, \mathrm{~B}_{6}\right)$ は，副反応によって生 成すると考えられる。未同定の $\mathrm{B}_{3}$ を除外して考えると $\mathrm{B}_{6}$ と $\mathrm{B}_{6}$ は,ブタジェン型エステルで， $\mathrm{B}_{1}$ や $\mathrm{B}_{\mathbf{4}}$ よりるさらに脱水素の進 んだェステルである。しかし，それらが $\mathrm{B}_{1}$ や $\mathrm{B}_{4}$ からの逐次反 応あるいは $\pi$-アリル中間体からの併発反応で生成すると考える ことはできない。なぜなら，それによっては，ブテンの種類によ って $\mathrm{B}_{6}$ や $\mathrm{B}_{6}$ の生成割合が異なる事実を説明できないからであ る。

$\mathrm{B}_{6} ， \mathrm{~B}_{6}$ の生成過程については，現状では不明の点が多いが， 著者らは一応つぎのように考えている。1-ブテンの反応を例にし て， $\mathrm{B}_{1}$ や $\mathrm{B}_{4}$ 生成反応との関係すあわせて示せば

$$
\begin{aligned}
& \mathrm{CH}_{2}=\mathrm{CHCH}_{2} \mathrm{CH}_{3}
\end{aligned}
$$

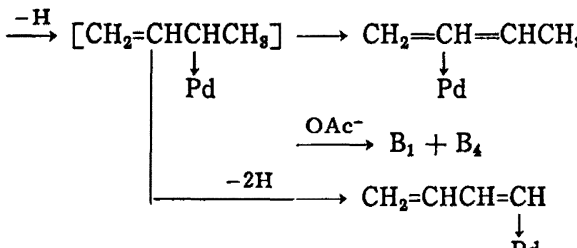

$$
\begin{aligned}
& \stackrel{\mathrm{OAc}^{-}}{\longrightarrow} \mathrm{B}_{6}+\mathrm{B}_{6}
\end{aligned}
$$

いずれの反応です脱水絜過程が必要であるが，それは，まずェ

13) G. C. Bond, P. B. Wells, Advan. Catal., 15, 91 (1964).
ネルギー的にもっとも有利なアリル水素について起こると考える のは自然であろら。それによって生成するのーフリルは一方では ただちに $\pi$ ーフリルを経て $B_{1}$ あるいは $B_{4}$ へ，他方では（触媒 活性が強いときはとくに）さらに脱水素を経て， $\mathrm{B}_{6} ， \mathrm{~B}_{6}$ へいた ると考える（たたしでタジェン型吸着種の吸着状態については上 記以外にひろいろのものも考えられよう)。この場合, 副反応 (6) が 2-ブテンより 1-ブテンで起こりやすい理由として, 1-ブ テンから導かれるのーアリルでは脱水素は（少なくてす 1 個は）ア リル炭素に隣接するメチル炭素位で起こるのに対して，2-ブテン からのすのでは, すっとるはなれた炭素位で起こらねばならない といら相違が考えられるかるしれない。なお，さきのプロピレン の反応では，この種の副反応が無視できるのは，プロピレンでは 2 個以上の脱水素がェネルギー的に困難であるといらことのため であろう。

以上のように金属パラジウム触媒によるオレフィンのアセトキ シル化反応では， $\pi$ アリル中間体機棈にしたがう反応（主反応） が起こるが，それ以外にさらに脱水素の進んだ副反応す併発しや すく, 反応条件次第では，副反応の方がむしろ主に起こるといら ことができる。このよに副反応が併発しやすいといら点で， ア セトキシル化反応は，さきに報告した水相䅗濁系におけるオレフ ィンの酸化反応と異なっている。オレフィンの酸化反応では, い ずれのオレフィンKついてる $\pi$ アリル中間体への水分子からの

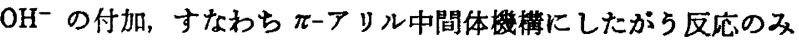
が起こり2) 万)14), 副反応はほとんど起こらない。両反応系におけ るこの相違が何に由来するかは興味深いが，これについて著者ら は, ブテンのアセトキシル化反応で, 触媒の乾嬠処理がブタジェ ソ型エステルへの副反応を増大させるという実験結果を考えあわ

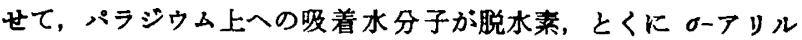
などからの脱水素に強い被毒作用をるっているのではないか，そ のために水相系の反応では副反応が抑えられるのではないかと考 えている。水分子のこのよらな選択的な被毒作用がどうして発現 するか明らかではないが，これは，炭化水素の気相接触部分䤇化 に扣いて水蒸気が完全酸化反応を抑制するといらよく知られた経 験的事実とも関連が深いように思われる。

14) Y. Moro-oka, " 1 st Soviet-Japanese Seminar on Catalysis", (July, 1971, Novosibirsk, U.S. S. R.) preprint.

\title{
Acetoxylation Reaction of Olefins over Metallic Palladium Suspended in Acetic Acidt
}

\author{
Noboru Yamazoe*, Yorinobu Goto**, Takao Tanaka* and Tetsuro Seiyama* \\ * Department of Applied Chemistry, Faculty of Engineering, Kyushu \\ University; Hakozaki, Higashi-ku, Fukuoka-shi, Japan \\ ** Present address ; Kasei Mizushima Co., Ltd.; Mizushima,
} Kurashiki-shi, Okayama, Japan

To elucidate the special catalytic action of metallic palladium in the partial oxydation of olefin, catalytic acetoxylation of propylene and $n$-butenes was investigated in acetic acid.

In the propylene acetoxylation catalyzed by metallic palladium, allyl acetate $\left(\mathrm{P}_{1}\right)$ was a unique product, although isopropenyl acetate was also co-produced over $\mathrm{Pd}$-activated charcoal catalysts (Fig. 1). On the other hand, the acetoxylation reactions of $n$-butenes were rather complicated (Fig. 2). In this case, the products, resulting from the catalytic action of metallic palladium, were $\mathrm{CH}_{2}=\mathrm{CHCH}(\mathrm{OAc}) \mathrm{CH}_{3}\left(\mathrm{~B}_{1}\right), \mathrm{CH}_{3} \mathrm{CH}=\mathrm{CHCH}_{2} \mathrm{OAc}\left(\mathrm{B}_{4}\right)$, cis as well as trans isomers of $\mathrm{CH}_{2}=$ $\mathrm{CHCH}=\mathrm{CHOAc}\left(\mathrm{B}_{5}\right.$ and $\left.\mathrm{B}_{6}\right)$, and an unidentified compound $\left(\mathrm{B}_{3}\right)$. Their relative amounts were 
changed sensitively by the species of $n$-butenes or the preparative method of the catalysts (Table 1 and Fig. 3).

In the case of the formation of $\mathrm{B}_{1}$ and $\mathrm{B}_{4}$ from $n$-butenes as well as that of $\mathrm{P}_{1}$ from propylene, the $\pi$-allyl mechacism is reasonably applicable to the main acetoxylation reaction, although side reactions should also be taken into account to explain the complicated course of the $n$-butenes acetoxylation. These are discussed in terms of the catalytic partial oxidation of olefin over metallic palladium suspended in water.

$\dagger$ Catalytic Oxidation of Olefins over Suspended Palladium Metal. II.

（日本化学会誌，1973，p. 690～696）

\title{
ウランーアンチモン系複合酸化物触媒の アクロレイン合成活性と触媒構造望2
}

\author{
（1972 年 12 月 12 日受理）
}

野 崎 文男・須郷 公 英*

既報飞継続して, U-Sb-O 系複合触媒の $\mathrm{C}_{9} \mathrm{H}_{6}$ から $\mathrm{CH}_{2} \mathrm{CHCHO}$ への酸化活性と触媒棈造との関 係を触媒調製法を変えたいろいろの触媒について検討してつぎのような知見を得た。共沈法扰よび沈着 法によって調製した触媒が活性および選択性にすぐれており，含漫法では選択性のよい触媒は得られな い。また触媒調製出発原料としての酸化アンチモンは $\mathrm{Sb}_{2} \mathrm{O}_{8}$ がよく, $\mathrm{Sb}_{2} \mathrm{O}_{6}$ では選択性のよい触媒は 得られない。触媒構造と選択的酸化能との関係は複襍で一義的に決められないが, 触媒調製過程中に複 合酸化物 $\mathrm{USb}_{8} \mathrm{O}_{10}$ の生成がみられる触煤が一般的に避択性がよい。 $\mathrm{C}_{8} \mathrm{H}_{6}$ 酸化反応を流通法とパルス 法とで比校して，触媒の種類によっては $\mathrm{CH}_{2} \mathrm{CHCHO}$ の $\mathrm{CO}_{2}$ への完全酸化が $\mathrm{O}_{2}$ の共存により抑制 される事実を見いた゚した。また触媒の ESR 測定から触媒中に $\mathrm{U}^{6+}$ と $\mathrm{O}_{2}^{-}, \mathrm{O}^{-}$などの常磁性種があ ること,および $\mathrm{U}^{5+}$ の存在量と触媒活性とは㨁接的な関係はないが $\mathrm{O}_{2}^{-}$や $\mathrm{O}^{-}$の存在は $\mathrm{CH}_{2} \mathrm{CHCHO}$ の選択的生成に重要な関係をるつことなどがわかった。

\section{1 緒雷}

ウランーアンチモン系複合酸化物触媒（以下，U-Sb 触媒と略 記する) の $\mathrm{C}_{8} \mathrm{H}_{6}$ から $\mathrm{CH}_{2} \mathrm{CHCHO} へ の$ 酸化活性と触媒粗造との 関係については一部をすで飞報告しだ)。著者らはそこで能煤調 製過程中に複合酸化物 $\mathrm{USb}_{8} \mathrm{O}_{10}$ の生成することが選択的酸化活 性の発現に重要であると結論した。るしこの結論が妥当であれば 触媒調製特の酸化アンチモンの酸化状態の如何が調製後の能媒の 構造に大きく影響し，その触媒活性に重大な影響を特よぼするの と推洘される。そこで本報告では触蝶調制時の出発原料物質とし $\tau \mathrm{Sb}_{2} \mathrm{O}_{8}$ と $\mathrm{Sb}_{2} \mathrm{O}_{5}$ とを選び，これにウラン成分を混合するさい と共沈，沈着捄よび含浸法と調製方法をがて U-Sb 触媒をつく り，その触媒活性と触媒構造との関係を検討した。その結果，既 報8) の知見をさら飞補足払㜊することができたのでここと報告す

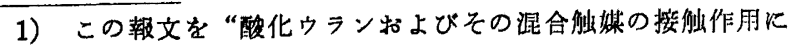
関する研究 (第 6 報)”之する。

2）前報(第 5 報)，野崎文男，市川文堆，日化，1973，254.

* 千葉大学工学部工業化学科, 千葉市弥生町

3）野崎文男，岡田 筧，日化，1972，842.
る。また本報告をまとめる㭙点において，Grasselli ら゙括とる

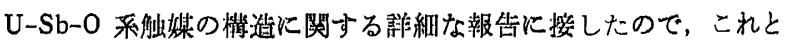
藷者らの吙見との比恔檢討も若下あわせて述へる。

\section{2 実験}

\section{1 实験方法}

$\mathrm{C}_{8} \mathrm{H}_{6}$ 接佂酸化反応の実験方法特よび $\mathrm{X}$ 線 回折, DTA-TGA, IR 吸収スペクトルなと仯蝶捎造に関する陚駼方法のいずれる既

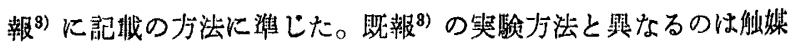

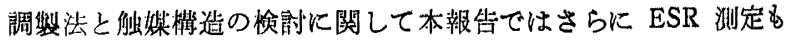
つけ加えたことである。

ESR 测定はつぎのようにした。真空排気处理和よびガス導入 ができるよらにコックをつけた内径 $4 \mathrm{~mm}$ の石奖製陚料管に能媒 陚料粉末を採取し， $400 \sim 450^{\circ} \mathrm{C}$ で $10^{-2} \mathrm{mmHg} ， 2$ 将間真空排気 した。必要に応して触媒を所定条件下で $\mathrm{C}_{8} \mathrm{H}_{6}$ 還元あるい性 $\mathrm{O}_{2}$

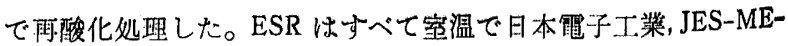
$3 \mathrm{X}$ 型X X゙ンドスペクトロメーターを用い，モデュレーションは

4) R. K. Grasselli, D. D. Suresh, J. Catal., 25, 273(1972). 